\title{
7: 150192644-150188547
}

National Cancer Institute

\section{Source}

National Cancer Institute. 7:150192644-150188547. NCI Thesaurus. Code C41934.

Physical location of CDK5_Gene 